\title{
When the State Speaks, What Should It Say? The Dilemmas of Freedom of Expression and Democratic Persuasion
}

\author{
Corey Brettschneider
}

\begin{abstract}
Hate groups are often thought to reveal a paradox in liberal thinking. On the one hand, such groups challenge the very foundations of liberal thought, including core values of equality and freedom. On the other hand, these same values underlie the rights such as freedom of expression and association that protect hate groups. Thus a liberal democratic state that extends those protections to such groups in the name of value neutrality and freedom of expression may be thought to be undermining the values on which its legitimacy rests. In this paper, I suggest how this apparent paradox might be resolved. I argue that the state should protect the expression of illiberal beliefs, but that the state (along with its citizens) is also obligated to criticize publicly those beliefs. Distinguishing between two kinds of state action - coercive and expressive-I contend that such criticism should be pursued through the state's expressive capacities in its roles as speaker, educator, and spender. Here I extend the familiar idea that law, to be legitimate, must be widely publicized; I contend that a proper theory of the freedom of expression obligates the legitimate state to publicize the reasons that underlie rights, in particular reasons that appeal to the entitlement of each citizen subject to coercion to be treated as free and equal. My theory of freedom of expression is thus "expressive" in two senses: it protects the entitlement of citizens to express any political viewpoint, and it emphasizes a role for the state in explaining these free-speech protections and persuading its citizens of the value of the entitlements that underlie them.
\end{abstract}

\section{Introduction}

$\Lambda$ recent report from the Southern Poverty Law Center suggests that hate groups advocating racist ideologies are on the rise after the election of the first African-American president. ${ }^{1}$ In the advanced democracies of Europe, studies of public opinion show that antiMuslim hostility is a growing problem. ${ }^{2}$ As evidence mounts of increasing bigotry, questions of how to respond to hate speech have become more pressing.

Corey Brettschneider (Corey_Brettschneider@brown.edu) is Associate Professor of Political Science at Brown University: I am grateful for comments at the early stages of the project during a workshop at the Safra Center for Ethics, and especially to Dennis Thompson, Philip Pettit, Sarah Conly, Archon Fung, Arthur Applbaum, and Jed Purdy. I thank my Brown colleagues David Estlund, John Tomasi, Sharon Krause, Jason Brennan, and Charles Larmore for comments during our PPW workshop. For helpful discussions about this paper I also thank Amy Gutmann, Jeff Spinner-Halev, James Morone, Rob Reich, Richard Fallon, John Goldberg, Lucas Swaine, James Fleming, Colin Bird, Paul Hurley, Nancy Rosenblum, and Steven Calabresi. I am grateful to workshop participants at the University of Pennsylvania for comments - in particular to
Traditionally, political and legal theorists have proposed two types of responses to hate speech. Some thinkers, such as Ronald Dworkin, have stressed the need for a neutral approach to rights protection. This group broadly defends the United States Supreme Court's current free speech jurisprudence, which does not protect threats or "fighting words," but otherwise does protect hateful political viewpoints from coercive sanction. By contrast, other thinkers have argued that free speech rights should not extend to viewpoints that promote values at odds with those of a liberal society. For example, Jeremy Waldron

Rogers Smith, Samuel Freeman, Nancy Hirschman, Ellen Kennedy, and Jeffery Green. I am also indebted to the members of the PEPA workshop at Princeton, including Charles Beitz, George Kateb, Stephen Macedo, Gil Harman, Elizabeth Harman, Peter Singer, Alan Patten, Melissa Lane, Jeff Stout, and Anna Stilz. I presented a late draft of this paper before a second group at the Safra Center. I thank the Center's new director Lawrence Lessig, as well as Eric Beerbohm, Daniel Viehoff, Frances Kamm, Frank Michelman, Nir Eyal, Moshe Cohen-Eliya, and Tommie Shelby. I also thank Perspectives on Politics' Editor, Jeff Isaac, and two anonymous reviewers. For excellent research assistance and very helpful substantive comments I am indebted to Minh Ly. 
has recently suggested that rights protection should not extend to hate speech, because such speech is a form of group libel. Thinkers in this second group broadly endorse the kind of legal limits on free speech found in countries such as the Netherlands. ${ }^{3}$

I find both these approaches problematic. The first group, the neutralists, fail to answer the challenge that hateful viewpoints pose to the values of freedom and equality essential to the legitimacy of a democratic state. As Simone Chambers and Jeffrey Kopstein point out, the viewpoints of groups such as the Ku Klux Klan and American Nazi Party constitute "bad civil society," in that they challenge the values fundamental to liberal democratic society. ${ }^{4}$ The alternative approach, however, which would encourage the state to ban hate speech, overlooks how the fundamental core democratic values of freedom and equality require states to allow citizens to develop and affirm their own political views.

I aim in this essay to propose and defend a third position that resolves these problems. I suggest that we distinguish between a state's coercive power or its ability to place legal limits on hate speech, and its expressive power or its ability to influence beliefs and behavior by "speaking" to hate groups and the larger society. On my view, the state should simultaneously protect hateful viewpoints in its coercive capacity and criticize them in its expressive capacity. In this way the state can protect the right to express hateful viewpoints and, at the same time, defend the values of freedom and equality against discriminatory and racist challenges.

My approach aims to answer critics of liberalism who contend that it is incapable of sufficiently addressing the threat to equality that might come from the domains of civil society and the family. Although liberal political theorists are committed to the values of free and equal citizenship, many believe this commitment requires the state to tolerate illiberal groups, such as the Ku Klux Klan, that oppose freedom and equality. In particular, liberal defenses of First Amendment freedoms imply to these critics that the protections of free expression, association, and conscience entitle the members of hate groups to promote their beliefs regardless of content. Because the liberal state must apparently tolerate groups that oppose its most basic values, liberalism is faced with a "paradox of rights": its commitment to free and equal citizenship in the public sphere is undermined by its protection of inegalitarian beliefs in the private sphere of civil society and the family. ${ }^{5}$ A variant of this criticism is made by communitarians, who worry that liberalism's neutrality and its protection of rights prevent those public values from being positively defended in public. ${ }^{6}$

I argue that to resolve the paradox, the doctrine of viewpoint neutrality must be contextualized within a larger theory of freedom of expression. The theory that I propose calls for the state to express the values of freedom and equality that ground the doctrine of viewpoint neutrality and estab- lish the legitimacy of democracy. The reasons that justify and limit coercion in a legitimate state should be consistent with these values. If the doctrine of viewpoint neutrality is grounded in the non-neutral values of freedom and equality, then the legitimate state should express and explain those values and attempt to persuade citizens to adopt them, using its expressive, as opposed to its coercive, capacities. Furthermore, the state should criticize illiberal and inegalitarian views at the same time that it protects the right to express those views. Here I extend the familiar idea that law, to be legitimate, must be widely publicized; I contend that a proper theory of the freedom of expression also obligates the legitimate state to publicize the reasons that underlie rights, a practice I call "democratic persuasion." The reasons it explains and promotes appeal to the entitlement of every citizen to be treated as free and equal. ${ }^{7}$

My theory of freedom of expression is thus "expressive" in two senses: it protects the entitlement of citizens to express any political viewpoint, and it emphasizes a role for the state in explaining these free-speech protections and persuading its citizens of the value of the entitlements that underlie them. In this second role, the state appropriately employs its expressive powers to convince citizens to adopt the reasons that underlie legitimate law. Although rights protections are central to limiting coercive state power, they are properly accompanied the duty of the legitimate state-in its expressive roles as an educator, a speaker, and a spender - to promote the values and reasons that justify those rights. In these roles, the state does not regulate expression; rather, it expresses itself to defend the very values that underlie the freedom of expression. Thus, liberty and equality need not be, as Catharine MacKinnon has suggested, on a "collision course." 8

In the next section of this essay, I examine viewpoint neutrality in the context of my wider theory of freedom of expression, and suggest why and how the values that ground this doctrine should be promulgated. In Section III, I develop the idea that the state, in its expressive capacities as speaker and educator, should promote the values of free and equal citizenship and criticize viewpoints at odds with the freedom and equality of citizens. Finally, and most potentially controversially, in Section IV I argue for why the state's expressive capacities also include its spending power. Throughout the essay I will draw on constitutional doctrines and case law to inform and promote a normative political-theoretical argument for a theory of freedom of expression that not only protects rights in a viewpointneutral way, but also provides an account of the proper role of the state in promoting the reasons that justify those rights.

\section{Neutrality and Coercion}

A theory of freedom of expression should incorporate an account of what the state would rightly "say" in its expressive capacity. On my account, state expression should be 
primarily concerned to articulate and defend the reasons and values that underlie basic liberal rights. This is the key to synthesizing the protection of rights and the promotion of equality and freedom of expression. I begin this section by clarifying why viewpoint neutrality should be theoretically grounded in non-neutral egalitarian values. I go on to suggest why this structure implies that free speech rights are "inverted," in the sense that the reasons for those rights are often at odds with the content of the speech that they protect. Finally, I argue that subject to two limits, the state has an obligation to act in its expressive capacity to explain why the reasons for protecting hateful viewpoints are at odds with the content of those viewpoints.

Viewpoint neutrality is the idea that the state cannot privilege one political viewpoint over others. The doctrine prohibits bans on the expression of viewpoints based on their substantive message. For instance, while the doctrine would not protect the atrocities committed by the Nazis, it would protect the right to defend Nazi ideology. It is worth clarifying precisely which kind of "hate speech" is protected under this doctrine and which is not. For example, the doctrine does not protect threats. The Supreme Court recently helped to clarify this distinction in Virginia v. Black by distinguishing between two kinds of crossburning. ' The Court classified as "unprotected" an act of cross-burning that threatened particular individuals with an "intent to intimidate." On the other hand, it classified as "protected" an act of cross-burning that generally expressed a hateful viewpoint, but in which no individuals were singled out as its targets. This suggests that an act of cross-burning may not necessarily be a direct threat, but might be the expression of a political viewpoint, albeit a viewpoint with a deeply inegalitarian message. In such cases, limiting it would be an unconstitutional departure from viewpoint neutrality. ${ }^{10}$

But why protect all viewpoint expression equally, especially if one is committed, as I am, to the premise of political liberalism that all coercion should be justified to citizens regarded as free and equal? The content of some doctrines, such as those of the Klan and the Nazis, are protected by viewpoint neutrality, yet they directly challenge political liberalism's commitment to freedom and equality. If these doctrines prevailed, they would subvert the basic principles of a legitimate democratic state. Viewpoint neutrality can be defended, however, in the liberal tradition by grounding it not in a viewpoint or value neutral justification, but in a commitment to treat all persons potentially subject to coercion as free and equal.

This defense, drawing on the thought of John Rawls, Ronald Dworkin, and Alexander Meiklejohn, connects viewpoint neutrality with a wider set of values that are required for political legitimacy. There is not room here to offer a full defense of the view that equality underlies the doctrine of viewpoint neutrality; my aim here is to suggest why the legitimate state is committed to action beyond the protection of rights if it embraces viewpoint neutrality. I will, however, sketch what I take to be a convincing value-based argument for adopting the doctrine of viewpoint neutrality. According to Rawls, political equality requires respect for the "two moral powers" of all citizens to develop and exercise what he calls a "capacity for a sense of justice" and a "capacity for a conception of the good." 11 Citizens cannot affirm and choose their own ideas about the most fundamental matters of politics and moral life if they are not free from the threat of coercion as they develop their own notions of justice and the good. Rawls' argument could be interpreted to support viewpoint neutrality, because the value of equality would be violated if some citizens but not others were free to develop their moral powers. This would be the case even if the state only banned the expression of inegalitarian viewpoints, because any government discrimination or non-neutrality among viewpoints would make respect for the exercise of these capacities unequal from citizen to citizen, and it would deny political freedom to citizens whose expression was so limited. Moreover, it would undermine the equal treatment even of citizens who did not hold the viewpoints in question, by failing to respect their capacity to make the free decision to reject those viewpoints. Respect for the two moral powers of citizens thus requires viewpoint neutrality. ${ }^{12}$

A similar line of egalitarian justification for this doctrine can be found in the work of Meiklejohn and Dworkin, both of whom oppose the banning even of the hateful viewpoints held by the Nazis and the Klan, because doing so does not respect the democratic autonomy of citizens to develop their own political opinions. Meiklejohn famously employs the metaphor of a town meeting to argue that all viewpoints must be protected in a democracy. On his view, while the moderator of such a meeting may legitimately limit speakers for reasons of time and relevance to the discussion at hand, censoring them based on the substance of their comments would obstruct the meeting's democratic aims. It would prevent those in the audience and other participants from hearing a variety of arguments for or against the measure under consideration, and it would constrain their ability to express their own views. Thus it would impede citizens' ability to be the source of their own democratic decisions, and so would undermine the democratic ideal. Hence, as with Rawls, for the state to discriminate based on the content of viewpoints would threaten its democratic credentials, even if those viewpoints were themselves deeply inegalitarian, because doing so denies the ability of citizens to affirm actively the core values of democracy. We must have the option of rejecting egalitarian values to be truly free to affirm them. As Ronald Dworkin puts it, "a majority decision is not fair unless everyone has had a fair opportunity to express his or her attitudes or opinions or fears or tastes or presuppositions or prejudices or ideals, not just in the 
hope of influencing others, though that hope is crucially important, but also just to confirm his or her standing as a responsible agent in, rather than a passive victim of, collective action." ${ }^{13}$ In short, citizens are entitled to hear and to make any political argument, because their status as equal citizens requires it. Neutrality thus should not be confused with a justification for free speech; it is rather a doctrine that informs us about when it is appropriate to limit coercion.

One might ask, however, whether it is empirically necessary for citizens to have the option to choose inegalitarian principles in order to develop the two moral powers or to deliberate about policy. Perhaps they would choose the same conceptions of justice and the good and develop the same policy views regardless of whether they had this freedom or not. However, I do not read the defenders of viewpoint neutrality as making an empirical argument, but as presenting a claim about what it means to respect citizens as free and equal. It is not that the protection of all viewpoints is actually necessary to develop the two moral powers or the capacities for democratic citizenship. Rather, the independent judgment of free citizens would be disrespected if the state restricted their options. Even if they ought not to choose views at odds with the ideal of equal citizenship, it is essential to legitimacy that they could choose them. ${ }^{14}$

So far I have sought to emphasize why defenses of viewpoint neutrality should be couched in a wider, non-valueneutral concern to protect the core values of freedom and equality which are linked to legitimacy. It follows from the grounding of the doctrine of viewpoint neutrality in this wider context that the legitimate state can and should protect some views that are at odds with its own core values. For instance, although some hateful speech is protected expression, it is deeply at odds with the conception of legitimacy that supports the very rights to speak and to associate that protect hate speech in the first place.

But this structural point leaves us with a seeming "paradox of rights": Does the commitment to viewpoint neutrality mean that the liberal state can say nothing about views which directly challenge its own value-based foundations? The theoretical structure of liberalism, I want to argue, has a normative implication that suggests a way out of this paradox. The liberal idea that coercion and the rights that limit coercion should be justified by appeal to reasons is a familiar one, as is the notion that the content of law should be promulgated to be legitimate. Laws passed in secret and never publicized are rightly held to be illegitimate, because citizens should be able to know when their actions are sanctioned by law, and when they are not. But this also implies that citizens should know, not just what their rights are or how they limit the coercive power of the state, but also the reasons for those rights and limits. The legitimate state, acting in its "expressive" capacities as opposed to its coercive ones, then has an obligation to explain why certain viewpoints that are pro- tected from being silenced by certain rights are at odds with those same rights.

The challenge lies in how the state might find an appropriate way to express the reasons underlying rights, given that it must also protect citizens' expression of ideas which might be at odds with those reasons. The kind of criticism that the state might bring against viewpoints that oppose free and equal citizenship will vary depending on the degree of that opposition. Some groups and some persons might hold some opinions at odds with democratic values while also holding other opinions consistent with these values. In such instances, the state should criticize the specific discriminatory views and avoid condemning the individuals and groups as such. Indeed, such specific views might best be criticized not through direct confrontation, but through the general promulgation of the reasons and arguments for rights. On the other hand, a group like the $\mathrm{Ku}$ Klux Klan presents a different case. The Klan is devoted entirely to opposing the ideal of political equality for all. Indeed, its founding ambition in the nineteenth century was to oppose the Equal Protection Clause of the Fourteenth Amendment, the clearest instantiation of equal status in the Constitution. The entire reason for the Klan's existence is to oppose the ideal of equal status and equal protection before the law. The obligation of the state in a case like the Klan's should not only be to criticize the group's beliefs, but (in its expressive capacity) to condemn the group entirely.

An example of the state expressing the reasons for rights and limits to the coercive power of the state would be found in Supreme Court decisions. The Court is ideally an "exemplar" of public reason in the sense that it acts as an enforcer of public reason considering the contours of rights, providing arguments that respect citizens as free and equal, and striking down unconstitutional laws, such as those that constrain the practice of free expression. On my view, however, it also acts as an exemplar of public reason in a second sense not explicitly identified by Rawls or other political liberals: it promulgates the reasons for those rights, and acts as a model for the wider citizenry, including public officials who deliberate about and make law, when it explains why certain laws are legitimate or illegitimate and when it speaks in defense of the values of free and equal citizenship. ${ }^{15}$ Supreme Court opinions certainly are concerned with the immediate question of whether or not to strike down a law. But their audience rightly includes all those even potentially involved in lawmaking, including citizens who are concerned to think and to deliberate publicly about law-making. The Supreme Court as an exemplar of public reason in this second sense captures the essential expressive role of the state in promulgating the reasons for rights. Ideally, the Court should explain to citizens that the state's protection of hateful viewpoints does not imply its approval of these viewpoints. In other words, the Court affirms the importance 
of rights such as free speech while giving reasons for those rights that criticize protected but discriminatory views. Such criticism should be understood not only as an attempt to persuade those with protected but discriminatory views to change their minds, but also to persuade other citizens that these views are at odds with core democratic values.

In the next two sections, I will elaborate on how other branches of the government can follow the Supreme Court's example in promulgating the reasons for rights. In the rest of this section, however, I want to clarify further my theory of freedom of expression by contrasting it with a noted "expressivist" notion of law. This view was developed in the areas of Establishment and Equal Protection Clause jurisprudence. ${ }^{16}$ As summarized by Elizabeth Anderson and Richard Pildes, expressivism says rights themselves should be understood, not as based on the interests of the individual, but rather as delineated by the expressive capacities of the state. Establishment Clause jurisprudence, for example, is best understood in terms of what the state should or should not express with its policies regarding religion. On this account, a cross in a public school classroom is problematic not because it coerces students, or even obviously affects their interests - they might simply ignore it-but because it sends the message that the state is endorsing Christianity, or that the state is a Christian one. Anderson and Pildes demonstrate that issues concerning religious establishment are inevitably linked to what the state should or should not say when it "speaks." The state will inevitably express messages as it acts-it is unlikely, for example, that public classrooms could avoid conveying any state message at all. The issue is not whether but what the state should say.

I do not wish here to dispute Anderson and Pildes' influential and important account of the Establishment Clause, but to discuss a problem their theory does not address with the tension between state expression and the protection of negative rights against coercive intervention distinct from their focus on direct state expression relevant to the Establishment Clause. ${ }^{17}$ The right to be free from state coercion in matters of individual expression requires a distinct kind of expressivist theory, because the way the state conveys its message in the area of free speech is inevitably more ambiguous than in an Establishment context. The jurisprudence of the rights related to the Establishment Clause concerns direct limits on what the state can say. To the extent that citizens have a right against the establishment of religion, they possess a right against the state endorsing any particular religion. The relationship between state expression and rights is perfectly congruent: the citizen's right against establishment of religion correlates with the state's duty not to establish a religion. But rights of freedom of expression are different. In this context, state expression can at times seem to be "inverted" when rights are invoked to protect speech that opposes the reasons which justify those rights. For example, the state's protection of free speech rights for hate groups might appear to suggest that the state offers no judgment about the racist content of their expression, or, worse yet, that it endorses those views. In this sense, there is a possible tension between the implicit message of speech protections and the reasons that are rightly understood to underlie those protections. Unlike in the case of establishment, where the promulgation of the reasons for rights will be reflected directly in state action, in the free speech context state action and the reasons for rights are inverted, in that the state protects speech at odds with the ideals of free and equal citizenship that theoretically ground free speech protections.

Given the possible confusion that inverted rights present for the successful promulgation of the reasons for rights, any workable theory of free expression should explain how the state might overcome this challenge. This requires finding a way to combine the protection of free speech rights with the state's expression and clarification of the reasons for these rights. The state's protection must be distinguished from its approval: the state should protect expression in a neutral way, but it should not be neutral regarding the content of all views protected by those rights. It can protect the right of free speech, while criticizing discriminatory viewpoints. It can promulgate the reasons for rights, including the value of equal citizenship, and seek to persuade all citizens to adopt those reasons as their own. This role for the state, which I call democratic persuasion, resolves the paradox of inverted rights and thus is a necessary complement to the rights protected under a doctrine of viewpoint neutrality.

To elaborate on the distinction between the state's policy regarding coercion and the state's role in promulgating the inverted reasons that justify rights, it is helpful to contrast my view with that of the critical race theorist Charles Lawrence (who in turn draws on the work of Richard Delgado). As Lawrence sees it, the state is always acting in its expressive capacities, because all state action, including coercion, is backed by reasons and value judgments. Lawrence, for instance, views the decision to desegregate lunch counters and the refusal to allow signs that bar entry to African Americans as themselves expressions of the state's support for the values of equal citizenship. ${ }^{18}$ Lawrence takes this approach to argue that the state should use criminal law to limit hate speech and prosecute hate groups. He argues, as I have, that these groups directly threaten the basic values of a free society, and that the state therefore must clearly condemn these groups. It rightly expresses this condemnation, he says, through the criminal law.

The problem with Lawrence's account, however, is that it fails to recognize the distinction between the type of value being expressed when the state acts in its expressive capacities, and the type of value being expressed by not limiting the expression of citizens and groups within society. When the state bans murder in criminal law, it is clearly expressing the idea that murder violates the rules of 
a legitimate society. Anti-discrimination law functions similarly; it expresses disapproval of the inegalitarian treatment of citizens. But not all decisions about coercion are the same. When the state protects the Klan's rights to association and free speech, it is not expressing support for the Klan's values, nor is it neutral about these ideas. Rather, it protects the Klan's expression for reasons related to respect for liberal principles of freedom. Lawrence's critique is helpful, however, in forcing liberal theory to clarify its reasons for refusing to regulate illiberal expression. When the state refrains from regulating illiberal viewpoints, it is essential that it also use its expressive capacities to clarify that it is not expressing support for the viewpoints themselves, but instead is guaranteeing an entitlement that stems from the need to respect all citizens as free and equal. On my account, the state can clarify the relationship between rights and the reasons for rights by clearly condemning hateful political viewpoints while protecting them from coercive law.

Consider in greater depth the Supreme Court opinion in Virginia v. Black. There, the Court found that a cross burning at a rally in which no member of the targeted class was singled out was protected expression. It invoked the doctrine of content neutrality, which is broader than but inclusive of the doctrine of viewpoint neutrality. The important point for our purposes is that the protected "speech" in this case- the burning of the cross-embodies values clearly in conflict with the normative reasons that underlie the legality of that speech in the first place. Liberal theories rightly justify the right of free expression and viewpoint neutrality based on the values of on free and equal citizenship. Yet they also should emphasize why the act of cross-burning is an affront to these values, because the reasons for the right to free expression which the state has the obligation to promote are at odds with the content of the speech protected by that right. Virginia v. Black is an example of how and why the state should explain the meaning of the right to freedom of expression to citizens. Without this explanation, there is a significant risk that the meaning of the protection of free expression will be misunderstood.

Legislatures considering passing coercive laws that would ban hateful viewpoints short of direct threats are certainly one of the Supreme Court's audiences in the Black decision. The Court's argument reminds these state actors why such laws violate the ideal of free and equal citizenship. But I want to suggest that the Klan and other hate groups themselves are another one of the Court's audiences. The Court's message to these groups is that, while their rights of free expression are protected, the content of their hateful views conflicts with the reasons for those protections. In addressing these citizens, the Court acts as an exemplar of public reason in the first and second senses I described previously-it is simultaneously protecting rights and promulgating the reasons for those rights.
Moreover, the reasons for rights as exemplified in Supreme Court opinions are not meant simply to be expressed publicly; they are also meant to be persuasive. At its best, the Court effectively defends the values of free and equal citizenship and of reasonableness. Indeed, its arguments should be offered as a model of democratic persuasion to challenge and change the minds of those who do not appreciate the importance of these values.

Of course, Supreme Court opinions on their own are unlikely to be effective in changing the minds of hate groups that oppose the ideal of equal citizenship. I assume that most members of hate groups are not thinking analytically about the nuances of First Amendment doctrine. So, although there is still an important expressive purpose to such opinions, we must acknowledge that they alone will not effectively persuade citizens of the reasons for rights. But no institution, including the Court, has a monopoly on the reasons that underlie rights-or on the reasons that could justify coercion in a legitimate state. Any state actor can and should appeal to these reasons. Later in this essay, I will make the case for this wider understanding of the expressive role of the state.

Political theory should be concerned not only with the question of rightful limits on coercion, but also with the question of how to express the reasons for coercion and its limits. When the state attempts to promulgate the reasons for rights without violating freedom of expression, it is essential that it observe two limits. The first, "meansbased" limit on democratic persuasion requires that the state not pursue the transformation of citizens' views through any method that violates fundamental rights such as freedom of expression, conscience, or association. For example, it cannot use criminal sanctions to prohibit meetings of the Klan on the grounds that its members reject the reasons for freedom of expression. However, a public articulation of why the Klan's views are inconsistent with the reasons for freedom of expression would be appropriate. On my view, the state can avoid crossing the meansbased limit by confining its method of communicating its message to its expressive rather than its coercive capacity. For example, public officials and citizens engaged in public discussion may make arguments that seek to transform hateful viewpoints. Moreover, as I will suggest in the next section, there is a wide role for educators and for the state more broadly in teaching the importance of the ideal of equal citizenship.

Since the notion of coercion is central to the meansbased limit, it is worth elaborating on how I will use this term. Drawing on Robert Nozick's work on this subject, I define coercion as the state threatening an individual or group of individuals with a sanction or a punishment with the aim of prohibiting a particular action, expression, or holding of a belief. ${ }^{19}$ Coercion on this view need not be successful; some criminals might risk incurring jail time. But the state employs criminal law in an attempt to deny 
citizens the right to decide to commit crimes. Nor does the mere fact that it is coercive imply, as some have inferred, that a state's action is unjustifiable. ${ }^{20}$ There are clearly justifiable cases of state coercion, such as laws against murder and assault. The means-based limit, however, suggests that the state should not use coercion to prohibit expression. Such threats would attempt to deny the ability of persons to decide for themselves what kinds of policy beliefs to hold. This denial would fail to respect the entitlement of those persons to develop their capacities as democratic citizens. It should be emphasized, though, that a state's attempt to change people's minds by expressing certain beliefs does not constitute coercion, since the state does not seek to prohibit them from holding conflicting beliefs. To the contrary, it is central to the idea of free expression and more specifically to the expression and defense of the core values of freedom and equality that citizens are free to reject it. Although I argue that the state should seek to persuade citizens to endorse these values, it is essential to values of freedom and equality that the state does not attempt to force acceptance. Citizens should be free to reject the state's defenses of the core values of free and equal citizenship.

The second, "substance-based" limit on democratic persuasion concerns both the kind of beliefs the state is rightly concerned to transform through its expressive capacity, and the circumstances under which the state is justified in exercising that capacity. It is necessary not only that the state exclusively use its expressive, rather than coercive, capacity to defend the ideal of equal citizenship, but also that it use its expressive capacity to challenge only those beliefs that violate the ideal of free and equal citizenship. In particular, the state should not seek to transform all inegalitarian beliefs, but only those that challenge the ideal of free and equal citizenship. As I have argued at length elsewhere, when we think about the reach of free and equal citizenship, we cannot a priori cordon off a private realm immune from its relevance. ${ }^{21}$ Intra-family decisions, for instance, might directly affect female children's chances for future equal citizenship if they were forbidden by their parents from receiving any education or learning to read. I therefore agree with Susan Moller Okin and other theorists of liberal feminism that, while the family and groups in civil society might be protected by rights of privacy and association, they still might make decisions that contradict the ideal of equal citizenship. ${ }^{22}$ It is important to clarify here that equal citizenship constitutes a political ideal; it is not the equivalent to equality in every sense. For instance, if I always neglect to pay the check at dinner with my friend, I might violate the ideal of an equal friendship, but not the ideal of equal citizenship. In sum, the substance-based limit on democratic persuasion obligates the state to express its condemnation only of views incompatible with an ideal of political morality, and not of those views that are incompatible with morality per se.
Also, there will be easy and hard cases — it is not always obvious whether a belief is incompatible with the ideal of equal citizenship and therefore subject to condemnation by the state. In my theory, it is only those views which are openly hostile to the ideal of equal citizenship, or implausibly compatible with it (for example, the claims of white racists that they are simply working to promote the equal treatment of whites in society) that the state has an obligation to condemn. ${ }^{23}$ Those who hold opinions that are plausible interpretations of an ideal of equal citizenship, even if they are controversial, should not be subject to such disapproval by the state in its expressive capacities. For instance, while some might think an ideal of equality requires affirmative action, those who disapprove of affirmative action are not expressing opinions that are hostile to or implausibly connected to the ideal of equal citizenship. Those who defend an ideal of colorblindness in hiring or admission processes in higher education also have a plausible claim to be arguing in a manner consistent with equal citizenship.

Particular citizens, politicians, or state actors might have their own opinions on questions about which there is reasonable disagreement, including questions about conflicting interpretations of equal citizenship. The substancebased limit on democratic persuasion concerns what the state is obligated to say on behalf of its own values. At times, the legitimate state articulates these values and their justifying reasons through state actors, and the substance-based limit should then be followed. But this certainly does not entail that state actors cannot articulate opinions on controversial matters when speaking for themselves. Moreover, although my focus is on instances in which the state is obliged to promote an ideal of free and equal citizenship and condemn viewpoints at odds with it, I hold open the possibility that other kinds of state speech might be neither obligatory nor prohibited. Pronouncements in favor of public health, including warnings about smoking or trans-fats, for instance, do not violate an ideal of equal citizenship, but neither are they required to clarify the meaning of equal citizenship. Such pronouncements might be permissible on grounds that are distinct from the ones I explore.

\section{The Reach of Democratic Persuasion}

I have argued so far that my theory of free expression accounts for the free-speech rights of individuals against state coercion and also obligates states to promote the values that underlie these rights. I have also maintained that the state must respect both the substance-based and means-based limits of democratic persuasion when it promotes these values through its expressive capacity. In this section, I begin to explore how the state might fulfill these duties by briefly examining how the theory applies 
to citizens in civil society. I hope to use this account of persuasion by citizens to begin thinking about how the state might change the minds of those who reject the values of free and equal citizenship and the reasons that underlie rights.

The idea of a role for public values in civil society might seem an odd starting point for a theory of free expression, given the usual understanding of the public-private distinction. In contemporary constitutional law, there is a distinction between public accommodations, such as hotels and lunch counters, which are regulated by civil rights law, and private clubs, which are protected by rights ancillary to freedom of speech, in particular the right of free association. But even if we recognize that free-association rights preclude the state from coercively interfering with private clubs, we can acknowledge that such clubs are not immune from public scrutiny and criticism. Members of these organizations are also citizens, and as such, they are obligated to respect the value of equal citizenship. Because racial discrimination, for example, perpetuates a historical exclusion of minorities from equal citizenship, citizens have a duty themselves to seek to transform discriminatory clubs. Club members are obliged themselves to resist racial discrimination in their club's policies, and citizens are obliged to refuse to join or to remain members if the club refuses to stop discriminating. ${ }^{24}$ Their right to join can coexist with their duty to leave.

In considering the implications of such a balancing act for the state, it is helpful to examine whether John Stuart Mill's defense of individual rights and the free exchange of ideas can exist alongside the robust duty of citizens to speak out against hate groups, racists, and others who challenge liberalism's very premises. Mill's famous epistemic argument that free speech will allow truth to win out over time rests on the premise that citizens have active duties to argue against speech that is protected in its expression yet wrong in its content. According to Mill, the defenders of inequality should be protected from coercion, but "remonstrating," "reasoning," or "persuading" them is acceptable. ${ }^{25}$ Mill did not, however, develop an account of why states, and not only citizens, might have a duty to reason with and persuade citizens of the importance of the values that underlie rights. Indeed, a sharp distinction between our duty to advocate as citizens and our general moral duties may be difficult to abide by in everyday discussion, because our moral and political duties are often intertwined. But when the state speaks, it is essential that it speak for all citizens and thus abide by the substancebased limit I elaborated in the last section.

In demonstrating the proper focus of democratic persuasion that seeks to promote the ideal of equal citizenship, it is helpful to examine the controversy that surrounded Supreme Court Justice Samuel Alito during his confirmation hearing. Alito was publicly criticized for his membership in a Princeton University alumni group that not only excluded African-Americans and women, but whose members had also opposed the admission of those groups to Princeton in the first place. ${ }^{26}$ In Alito's confirmation hearing, members of the Senate Judiciary Committee acted in their official capacity to ask Alito about his membership and his reasons for joining. Here, reasoning by both citizens and state officials sought to transform beliefs and behavior clearly protected by rights. The hearings served not only to bring to light the discriminatory views of the club, but to persuade citizens listening to the hearings that those views are incompatible with public values. ${ }^{27}$

This case suggests why and how the duty to defend the values and reasons that underlie rights-in particular, a concern for equal citizenship — should be pursued not only by citizens, but also by the state in its expressive capacity. In the Alito case, the Senate was exercising its public power to decide whether to confirm a Supreme Court Justice. Given the discretion of judges in deciding cases, it is important that they not oppose the basic values and reasons that justify rights. Those who appoint them or confirm their appointments, therefore, should consider whether they oppose the values of freedom and equality that justify rights, or have acted in a manner that raises questions about their commitment to those values. Alito's membership in the Princeton club was rightly subject to scrutiny because the club opposed the ideal of equal citizenship. No one in this debate disputed Alito's right to join the club as a matter of law; rather, the issue was whether his decision to join violated the basic public duties of nondiscrimination-particularly when membership in organizations like the club is linked to future job opportunities, as well as to political and financial power. Moreover, the threat of being voted down for the job of Supreme Court Justice by the Senate is not a coercive threat, in my definition, since not being confirmed does not deny him the right to belong to the club. ${ }^{28}$

Exercising the state's expressive and persuasive capacity to defend the reasons for rights is a duty of state officials more generally. State officials like Supreme Court justices are exemplars of public reason in the second sense, promulgating the reasons that underlie rights and seeking to change the minds of those who reject the liberty and equality of citizens. When they do so, state officials are not expressing general moral views, much less a comprehensive good or religious doctrine. Rather, they are invoking core ideas of political morality related to equal citizenship. The officials respect the substance-based limit of democratic persuasion, in that they speak on behalf of the core values of value democracy, and not on behalf of their own comprehensive conceptions. Other kinds of private behavior, however, should not be subject to democratic persuasion. For instance, I do not believe that questions of sexual morality are obviously connected to public values of equal citizenship. An inquiry centered on whether a nominee to the Court had multiple consenting sexual partners, for 
example, would go beyond the substance-based limit on democratic persuasion. Thus, during Justice Clarence Thomas's Senate confirmation hearing, sex itself was not properly an issue. Thomas was being asked about sexual harassment, an issue linked to his regard for women as equal citizens, and clearly a matter of public relevance.

Some might object that there is a difference between citizens having an expressive duty to articulate the values of free and equal citizenship and the state having a similar duty. The difference, according to this objection, is that state action - even when limited to expression-falls into the category of coercion per se. However, I would reply that the state, in some of its roles, is clearly reasoning and persuading, not coercing. For instance, in the Alito hearing, the committee members did not attempt to force Alito to reject the values of the Princeton club. Instead, they used public dialogue and public scrutiny to demonstrate that the club's discriminatory policies violated the wider public value of equality. Moreover, this inquiry respected both of the key limits that I have proposed on democratic persuasion. The Senators respected the rights of citizens and the means-based limit, in that they never threatened to prohibit the beliefs they criticized. Furthermore, the inquiry respected the substance-based limit by raising only the publicly-relevant matter of whether Alito held beliefs at odds with the value of equal citizenship. Insofar as the Senators referred to the ideal of equal citizenship, they were speaking not merely in their capacities as representatives of their constituents, but on behalf of the values fundamental to the state's legitimacy.

The contemporary state can "speak" in favor of its own values - and against those who deny the freedom and equality of citizens - in a variety of ways, ranging from the direct statements of politicians to the establishment of monuments and public holidays. Martin Luther King Day and Black History Month, for instance, are examples of official endorsement of the civil rights movement's struggle for equality. In celebrations and commemorations of these days, public officials do not shy away from political viewpoints. Rather, they articulate a defense of the value of equal status and celebrate those citizens who promoted it. Far from being viewpoint-neutral about Southern segregation or groups like the Klan, the state promotes a particular viewpoint in defense of equal protection. Of course, citizens have the right to dissent from such expression. But here the state and its citizens should stand together to express disapproval of those who defend segregation in our society or who, more subtly, lament the end of "states' rights" that would protect segregation.

Another way for the state to express and promote the value of equality is through its actions as educator. When state standards require that the history of civil rights and the struggle against groups like the Klan be taught in schools, for instance, these matters are not taught in a viewpoint-neutral way. The movement and its victories are rightly taught as part of the American effort to live up to our proclaimed values of equality. The hope of public educators in teaching the lessons of Martin Luther King Day and Black History Month is that, regardless of what they are taught at home, at school students will learn the value of equal status for all citizens.

Some might object here that, because children are forced to attend school, the state acting in its capacity as educator is not expressing values, but coercing students into accepting them. In response, it is essential to remember the means-based and substance-based limits which I have proposed to state expression. Civic education must not undermine the values of free and equal citizenship. Teachers, for instance, should be careful not simply to silence dissenting students, even when dealing with inegalitarian views. They should instill respect for basic liberal values by reasoning with students. Teachers should not force beliefs on children, just as the state should not force beliefs on its adult citizens. Indeed, to require students to pledge allegiance to or recite a lesson's object values conflicts with the value of respect for each individual as free and equal. More appropriate curricula would encourage students to reflect on these matters and to debate hard cases. Such encouragement, however, is not viewpoint- or value-neutral. Teaching methods should attempt to instill a respect for reasoned discourse as well as a recognition of the values of free and equal citizenship that underpin this respect. Similarly, to respect the substance-based limit on state action, teachers should frame issues for their students in light of the state's duty to respect, not just any values, but those of free and equal citizenship.

I have argued so far that the state is obligated to promote equality through its formal educative or expressive capacity and by engaging in democratic persuasion. One potential problem with this account is that this obligation may conflict with the free-speech rights of government employees. Imagine a case in which a public school teacher was fired for promoting hateful views in the classroom-say, those of the Ku Klux Klan. Such a case would pit the free-speech interests of the teacher against the school's and the state's interest in promoting the value of equal citizenship. Since the Klan member, in serving as a public school teacher, would threaten to undermine the value of equal citizenship rightly viewed as at the heart of a civil-rights curriculum, on my view the school would be justified in firing the teacher, because of the state's obligation to promote the fundamental values that underlie rights. To assert the free-speech rights of the teacher would be a misplaced invocation of an "inverted" free-speech right, where the hateful viewpoint of a public worker would be protected at the expense of the state's ability to explain the reasons for free speech. I would even argue that this kind of hateful expression by the teacher could be grounds for dismissal even if done outside the classroom or the school—say, in a newspaper 
editorial or in a public speech. Such behavior also would likely undermine the teacher's ability to convey the school's message of equal citizenship.

In short, while "inverted" rights of free speech appropriately protect hateful viewpoints such as the Klan's, they do not entitle those voicing such views to work officially for the state. Although firing might seem coercive, and in this case it is carried out by the state, it is not "state coercion" as I have defined it. The state is not attempting to deprive all individuals of the choice of whether to adopt a hateful viewpoint. It thus respects viewpoint neutrality more generally. But when it comes to the specific question of whether it will fund views at odds with its core values, it refuses to provide positive support for hateful viewpoints by employing those who endorse them. There is no general right to be employed by a public school any more than there is a right to sit on the Supreme Court. A requirement for both positions is that an occupant does not undermine the state's duty to promulgate the reasons and values that underlie rights.

Importantly, however, a case in which a teacher was fired for preaching hateful views should be distinguished from an instance in which a teacher was punished for resisting a school policy that has no bearing on questions of free and equal citizenship. For instance, if a teacher were protesting the school administration's budget priorities, this kind of speech ought to be protected, because firing the teacher would violate the substance-based limit on democratic persuasion. ${ }^{29}$ Only if the teacher's views were explicitly opposed to the value of equal citizenship, or if they were implausibly connected to that value, could that teacher justifiably be fired on the grounds of state promotion of the core values central to legitimacy.

\section{Democratic Persuasion and the State's Spending Power}

The state also acts in its expressive capacity in its role as spender of public funds. Here, its power in contemporary society is significant. If we combine what the state spends directly on various programs with grants it provides to private organizations, government expenditure is a large portion of the gross domestic product. ${ }^{30}$ This power raises the concern that the line between the state's coercive and expressive capacities may be blurred. In response, I will defend a role for the state's spending power as an expressive capacity rightly used to promote values of equal citizenship. This should not be the state's only goal, but it should pursue its projects in a way consistent with the core political value of equal status. Of course, as I will explain, if the state is to be effective in using its spending power to promote and protect the values of free and equal citizenship, it should not use this power without also expressing the reasons for doing so. At the end of this section, I also consider the related issue of whether non- profit status may be denied to a group as a way of expressing disapproval of that group's direct challenge to the ideals of free and equal citizenship. I suggest that denying nonprofit status to a group, like denying state funds, should be conditioned on whether the group's views undermine the ideals of free and equal citizenship central to the state's legitimacy.

The chief concern critics will likely find with my proposal is that extending the state's expressive capacities to include its spending power may violate the means-based limit on democratic persuasion. The concern is whether threatening to deny funds to an organization that holds views at odds with the reasons for rights-including a basic regard for equal citizenship-crosses the line from expression to coercion. Although denial of funds is not the same as criminal punishment, it might be regarded as a sanction, and thus a violation of the core right of freedom of expression. Just as those with hateful views have a free-speech right not to be punished by the state for those views, some will argue that they also have a right not to be sanctioned financially. The best argument for the claim that spending power is coercive focuses on instances in which no other funds are available to facilitate one's expression than those provided by the state. For instance, if the only media outlets were owned by the state, and the state failed to provide access to these outlets for those with hateful viewpoints, then arguably, their rights to free expression not only would have been diminished, but violated. Or, imagine that a state library had exclusive control over access to a set of rare books favored by hate groups. Denying such groups access to these books, even if the books would be used to further a hateful ideology, would be equivalent to cutting off their free-speech right coercively, because the library in this instance would be citizens' only means of gathering this information.

Following Rawls, we might distinguish between the freedom of expression and the "worth" of that freedom. ${ }^{31}$ Without the financial means to exercise a free-speech right, the right might arguably have no real worth. Therefore, in a world where denying state funds is equivalent to denying any ability to exercise the rights of free expression, citizens should have a claim against the state withdrawing funding. This concern suggests the general importance of a just distribution of wealth, which would also grant citizens the financial means to pursue their own expression. Once the worth of liberty has been guaranteed, citizens have the option and the means by which to resist state incentives that promote the government's message.

But there is an important contrast between the financial inducements I am considering here and state coercion. State coercion is employed in an attempt to deny the ability to make a choice. A parking fine as a penalty for parking in a red zone, for instance, does not allow citizens to choose whether they wish to pay to park in a red zone; the goal of parking fines is to force citizens not to park in 
those zones. By contrast, offering financial inducements, like pure persuasion, is clearly an attempt to convince citizens to make a particular choice, but it does not deny the citizen the right to reject that choice. While potential state funding can serve as an incentive to believe certain ideas, citizens might legitimately choose to reject those beliefs and forgo those funds.

I now want to turn to instances in which the state might or might not use its spending power to promote the value of equal citizenship. In a line of cases about whether the government can condition its spending power on certain expressive goals, the Supreme Court has oscillated between two categories. In the first category of cases, it has found that when the state creates a "public forum" for "private speech," it cannot condition its spending power on an "unconstitutional condition," namely that the institution or individual abandon constitutional rights. ${ }^{32}$ In this category, the Court has suggested that viewpoint neutrality is required in order to avoid an unconstitutional condition that would limit free speech. In a second category of cases, which I call "spending as sponsored expression," the Court has suggested that when spending is used to express a government-sponsored message, the state can place restrictions on the content of speech regardless of the nature of that speech. On my view, both categories have a distinct but equally flawed conception of neutrality at their core. The first wrongly assumes that there should be a neutral test for state subsidies of "private speech." The second of the Court's categories wrongly assumes that the test for what the state can rightly express should be a neutral one.

The Court applied the "public forum" doctrine in Rosenberger v. University of Virginia, a case that concerned whether a public university that funded student organizations could deny money to a group that produced a religious publication. ${ }^{33}$ It did not examine the case on grounds of religious freedom; it instead turned to an analysis based on free speech. The Court decided this case on First Amendment grounds, invoking a standard of viewpoint neutrality. It suggested that when a public university creates a public forum to allow a variety of ideas to be heard, it cannot discriminate based on the mission or viewpoint of different organizations participating in the forum. In the Court's terms, the university established a public forum, which triggered in turn a requirement of viewpoint neutrality.

Although I do not dispute the specific outcome of this case, I do believe it a mistake to suggest that any time a "public forum" is established, freedom of expression requires viewpoint neutrality. This approach would mean that a public subsidy could be demanded by groups which espouse values fundamentally at odds with the ideals of equal citizenship. ${ }^{34}$ Consider the question of whether a state university would have to fund a student-based group that opposed the admission of women and racial minorities to the school, similar to the alleged views of Justice Alito's alumni club at Princeton. I argue that members of this group might have a right to speak on campus, publish in the student newspaper, or espouse their views in the classroom, but this does not imply a right to be subsidized by the school..$^{35}$ Moreover, if a public university found that discriminatory viewpoints were spreading on campus, it would have an important obligation to challenge these views, and it could use its spending power to do so. Nothing in such a policy would limit the free-speech rights of students to associate or organize, but the public university would rightly express the reasons to respect the freedom and equality of all citizens, and it should criticize the racist or discriminatory views that contradict those values. In this sense, the beliefs of such groups are not "private." And such groups can organize and raise funds without receiving financial support from the university. For example, members of the Princeton club were alumni, but a club with the same mission and made up of current students also could have raised funds without university support. This suggests that rights to free speech and association are not violated simply because a university denies a group funding. The question of subsidy differs from a case in which a group that espouses hateful viewpoints but does not threaten students is banned outright on the campus of a public university. Such a ban would be an illegitimate use of the state's coercive capacity because it violates the group's rights. However, simply limiting funding is a way for the state to promote equality without violating rights.

The "sponsored expression" doctrine has a more subtle but equally problematic conception of neutrality at its core. During the first Bush administration, for example, clinics that received federal funds were banned from telling patients about their right to an abortion. Viewing the rule as a coercive restriction, abortion and free-speechrights plaintiffs brought a suit to challenge what became known as the "gag rule." The Supreme Court in Rust v. Sullivan determined that the state violated no rights, because the state was using its spending power to express directly its own point of view, in a manner similar to when it has its own employees express any other message. ${ }^{36}$ In order to avoid the application of the public forum doctrine and its prohibition on unconstitutional conditions, the Court suggested that the clinics in this case, including their doctors, were speaking on behalf of the state. The Court concluded that, because the state was not acting in its coercive capacity, the state could condition its use of funds on a non-viewpoint-neutral requirement, like the gag rule.

I find the distinction between the state expression in Rust and "private speech" in Rosenberger dubious. The issue in both cases is whether the government can use its spending power to promote or condemn particular nonneutral values and viewpoints. It is likely that the doctors 
in this case did not view themselves as promoting a governmental message, any more than the students in Rosenberger saw themselves as promoting the message of the school. In that sense, both cases are about the right of the state to use its spending power to influence citizens and groups in non-neutral ways. And, although I agree with the Court's contention in Rust that the state need not be viewpoint-neutral because of its expressive interest, I want to take issue with its conclusion on the grounds that the state violated the substance-based limit. The Court was unable to recognize this fundamental problem with the state's expression in Rust, because it was neutral with regard to the content of what the state expresses. In the case of the gag rule, the state expressed itself in a way inconsistent with the most basic values of a legitimate society, violating the substance-based limit. The authors of the rule sought to deny information to citizens, not only about their medical options, but also about their legal rights. In a democracy, hindering access to information about basic rights keeps citizens both from being treated as equals and from being treated as free individuals capable of making their own decisions. Withholding such information suggests that citizens are incapable of making their own decisions about what to do with their rights. Although the state acted in its expressive capacity and thus was not violating the means-based limit in the gag-rule case, the position it expressed was at odds with the core values of a liberal democracy. It is important to emphasize here that my concern has to do with the policy of denying information about a right to free citizens. I do not mean to suggest, in emphasizing a right to information, that the state should take a position in its expressive capacity in order to persuade citizens of the merits—or lack thereof-of abortion as such.

Throughout this essay, I have delineated a theory of the freedom of expression that calls for the state to actively promote particular values. Just as the state would violate its mandate as a speaker if it were to preach inequality, so too, by denying access to information in the gag-rule case, the state failed to promote the right values. The gag-rule case thus demonstrates that rights are not the only limits on legitimate government action. The substance-based limit on democratic persuasion establishes that the content of the state's expression - the reasons it gives for rights - should focus on the promotion of the ideal of free and equal citizenship. In Rust, the state's very act of expression undercut the promotion of a free and equal citizenry by denying citizens access to information about some of their most basic rights. Moreover, Rust serves as an example of state expression that is illegitimate, and therefore illustrates why my theory of democratic persuasion does not merely aggrandize state power. To the contrary, it shows how some state expression might inappropriately violate the basic ideals of free and equal citizenship, and therefore run contrary to the very notion of democratic persuasion. The democratic value of free and equal citizenship provides a normative standard to limit and to evaluate instances of democratic persuasion, the same way that principles of democratic legitimacy limit and evaluate instances of state coercion.

In short, both the categories of "public forum" and "sponsored expression" invoke a mistaken conception of neutrality. I have sought to challenge this emphasis on neutrality, arguing that state funding can and should be used to promote the core values of free and equal citizenship and to condemn viewpoints that challenge these values. The power to spend is one of the means for the state to promulgate effectively the reasons that justify rights. In this respect, the state is not a neutral umpire among competing views, especially when it comes to those views that challenge the very reasons and values that underlie rights. Nor are beliefs that are incompatible with the ideal of equal citizenship "private" in the sense that the state has no role in seeking to change them. On the contrary, the state should seek simultaneously to protect the freedom of expression from coercion and to persuade those who hold viewpoints at odds with the state's own core values to change their minds. Particularly when it comes to the promotion of the ideal of equal citizenship, the state should express the very values that underlie freedom of speech in the first place.

\section{Conclusion}

Theorists such as Rawls and Meiklejohn may be interpreted to support a viewpoint-neutral conception of the right to free expression. This viewpoint-neutral conception has been influential in the Supreme Court. I have argued, however, that viewpoint neutrality is undergirded by a non-neutral ideal of free and equal citizenship. Moreover, I have proposed that the state has an obligation to promote rights such as free expression through its expressive capacity. The state should promulgate, not only the content of rights, but also the reasons for those rights. The challenge presented by freedom of expression is that the neutral right of free speech — unlike rights against the establishment of religion or to equal protection of the laws-is "inverted" with regard to the reasons for that right. I have argued, however, that protection of free expression should be accompanied by a robust direct expression of equality through the state's expressive roles as speaker and spender. In these roles, the state should seek actively to combat the beliefs of groups such as the Ku Klux Klan and the American Nazi Party that are opposed to the values and reasons undergirding the freedom of speech, while protecting their free speech rights to express those beliefs. While viewpoint neutrality has a place within liberal democratic theory, it should be complemented by democratic persuasion, in which the state expresses the reasons and values that justify rights, and criticizes views that deny the freedom and equality of all citizens. 


\section{Notes}

1 See Associated Press 2009 and Holthouse 2009.

2 For example, Paul Sniderman's When Ways of Life Collide, the subject of a recent symposium in this journal, suggests increasing bigotry towards Muslims is present in the Netherlands. See Sniderman 2007 and Isaac et al. 2008. If such attitudes do indeed become more prevalent, we might expect an increase in organized hate groups.

3 The Dutch approach to banning hate speech has received greater attention, since the recent indictment of the Dutch lawmaker Geert Wilders. Wilders, who has called for banning the Koran, has been accused of inciting hatred toward Muslims. See Buruma 2009. Interestingly these laws have been passed through the democratic process, despite what Sniderman sees as rising prejudice against Muslims in that country. See Sniderman 2007 and Isaac et al. 2008.

4 Chambers and Kopstein 2001.

5 Feminist critics of liberalism, such as Wendy Brown, and liberal feminists alike have argued that, in many of its common forms, liberalism fails to recognize deep inequality within the family because the family is regarded as private. See in particular Brown 1995.

6 Michael Sandel suggests that liberalism's protection of the rights of civil society groups and its neutrality toward the values present in civil society have rendered it ineffective in fostering a culture of equality. See Sandel 1996 and Glendon 1993.

7 For a discussion of the meanings of these values, see in particular Rawls' discussion of the "liberal principle of legitimacy" in Rawls 1993.

8 MacKinnon 1993, 71.

9538 U.S. 343 (2003).

10 In Justice O'Connor's words, "As the history of cross burning indicates, a burning cross is not always intended to intimidate. Rather, sometimes the cross burning is a statement of ideology, a symbol of group solidarity." Virginia v. Black, 538 U.S. 343 (2003), 365-66. Although the Court's protection of free speech goes beyond viewpoint neutrality to protect content neutrality (with a few exceptions), I focus my inquiry here on viewpoint neutrality, the "core" of first amendment speech protection.

11 Rawls 1993, lecture 8, especially 302, 332, and 334-35.

12 Rawls endorses viewpoint neutrality; see Rawls 1993, 336: "So long as the advocacy of revolutionary and even seditious doctrines is fully protected, as it should be, there is no restriction on the content of political speech, but only regulations as to time and place, and the means used to express it." However, the literature on Rawls is divided over whether viewpoint neutrality extends to hate speech, as he did not address the issue explicitly in his work. See Freeman 2007, 72.

13 Dworkin 2006.

14 In a book-length work, I have defended the idea that respect for free and equal status requires a respect not only for democratic rights of participation but also a respect for rights protections. See Brettschneider 2007a.

15 Rawls calls the Supreme Court an "exemplar" of public reason. It is clear he means to do so in my first sense, but it is unclear whether he would agree with my extension of this term to the second sense, that the Court should be an example for the wider citizenry. See Rawls 1993, 231.

16 Pildes and Anderson 2000.

17 My focus is on the right to free speech, but a similar analysis might be given of other negative rights- for instance, the right to privacy.

18 Lawrence 1993.

19 Nozick 1997.

20 I do not, therefore, rely on a moralized conception of coercion. In a moralized conception, an act counts as coercion only if it is not moral, in the sense of not being fully justified. For the moralized conception, see Wertheimer 1987. However, my definition differs from the moralized conception, in that it acknowledges that certain acts can be morally justified and yet coercive. My definition uses the non-moral but normative criterion that acts count as coercion when they attempt to deny a choice. For discussion on this point I thank Eric Beerbohm and Daniel Viehoff.

21 For an elaboration of this argument see Brettschneider $2007 \mathrm{~b}$

22 Okin 2004.

23 I am thinking, for instance, of the case of former Klan Grand Wizard David Duke, whose National Association for the Advancement of White People masks clearly inegalitarian views in the language of equality. On its website (http://www.davidduke. com/general/what-is-racism_32.html) is the misleading claim that it "campaigns merely for the equal treatment of all races."

24 Nancy Rosenblum is widely regarded as a preeminent defender of free association rights for clubs that discriminate. She suggests that the incongruity between a club's private inegalitarian values and the public commitment of citizens to equality is defensible because these clubs present utilitarian benefits to society as a whole. They channel what might be the political violence of extremists, for example, into social organizations where they can be better controlled. They provide a psychological outlet, moreover, for inegalitarian beliefs and so protect the public realm from such beliefs. I believe, however, that these arguments go to matters of coercion. They 
do not suggest whether, qua citizens, we should oppose such groups in our non-coercive capacities. See Rosenblum 2000.

25 Mill 1975, 15. At times, however, these duties to persuade become conflated for Mill with wholesale attacks on religion. In particular, see his comments on Mormonism in the last paragraph of Chapter IV (112).

26 See Stevenson and Lewis 2006 and Kirkpatrick 2005. The club claimed at one point to merely be opposed to affirmative action, but news reports make this claim suspect at best.

27 It is important that the inquiry did not concern a mere debate over affirmative action, or preferences in college admissions, but about the mere presence of African-Africans at Princeton. While the debate about affirmative action lends itself to multiple plausible interpretations of that practice's implications for equal citizenship and thus does not obligate the state to take a particular position on it, the same is not true of the question of whether African-Americans have a place at an elite educational institution.

28 The same kind of reasoning that makes the Alito hearings inquiry into his membership in the Princeton club might also have applied to a Senate inquiry into Senator Edward Kennedy's membership in a networking club that excluded women, if he had not resigned his membership voluntarily. Such clubs arguably reinforce networks of male power in their exclusion of women.

29 In Pickering v. Board of Education, 391 U.S. 563 (1968), the Supreme Court considered the case of a teacher fired for criticizing the spending priorities of a school on the grounds that it undermined the school's interest in efficiency. Such a neutral analysis, however, would be misplaced in the kind of case I have just described. I go on, in the next section, to elaborate on why neutral evaluations of state speech are mistaken.

30 The Bureau of Economic Analysis of the U.S. Department of Commerce estimated the U.S. gross domestic product (GDP) in the fourth quarter of 2007 to be $\$ 14.08$ trillion and the portion of GDP contributed by "Government consumption expenditures and gross investment" to be $\$ 2.77$ trillion. Government spending thus accounted for $19.68 \%$ of U.S. GDP. See U.S. Bureau of Economic Analysis 2008.

31 See Rawls 2001, 179 and Rawls 1993, 325-326.

32 Sullivan 1989.

33515 U.S. 819 (1995).

34 A related issue is present in the case of Bob Jones University v. United States, 461 U.S. 574 (1983). There, the Internal Revenue Service denied 501(c)3 tax status to the university on the grounds that its policy banning interracial dating was at odds with the public purpose of educational institutions. On my view, this was the right decision, given Bob Jones' explicit opposition to rights to interracial marriage, a viewpoint I consider to be at odds with the ideal of equal citizenship.

35 In the recently argued Supreme Court case, the Christian Legal Society challenged the University of California, Hastings College of the Law's policy of not funding discriminatory student groups. The Christian Legal Society argued that the school's denial of funds discriminated against the Society's viewpoint that homosexuality is immoral. Although Hastings denies that it is infringing the Christian Legal Society's viewpoint, I would suggest another approach, based on my theory of democratic persuasion. The Court should find that Hastings is entitled to promote a policy of non-discrimination, even if the policy results in not actively funding discriminatory viewpoints. For instance, Hastings should not be forced to fund a hate group, nor should it be forced to fund a group that supports discrimination. Refusing to fund a discriminatory group would not violate the rights of the Christian Legal Society, because Hastings does not ban the group from campus or exercise a coercive threat. Rather, it expresses its disapproval of discrimination by refusing to actively support the group with the public university's funds. This is consistent with the aim of democratic persuasion to protect discriminatory groups from state coercion while still criticizing their discriminatory views. See Christian Legal Society v. Leo P. Martinez, 561 U.S. (2010). 36500 U.S. 173 (1991).

\section{References}

Associated Press. 2009. "Neo-Nazi Group Resurfaces, Citing Obama," New York Times (April 26):

A19.

Bob Jones University v. United States, 461 U.S. 574 (1983). Brettschneider, Corey. 2007a. Democratic Rights: The Substance of Self-Government. Princeton: Princeton University Press.

_ 2007b. "The Politics of the Personal: A Liberal Approach.” American Political Science Review 101(1): 19-31.

Brown, Wendy. 1995. States of Injury: Power and Freedom in Late Modernity. Princeton: Princeton University Press.

Buruma, Ian. 2009. "Totally Tolerant Up to a Point" New York Times (January 29): A29.

Chambers, Simone and Jeffrey Kopstein. 2001. "Bad Civil Society.” Political Theory 29(6): 837-65.

Christian Legal Society Chapter of University of California, Hastings College of Law v. Leo P. Martinez, 561 U.S. (2010). 
Dworkin, Ronald. 2006. "A New Map of Censorship." Index on Censorship 35(1): 131-33.

Freeman, Samuel. 2007. Rawls. New York: Routledge.

Fuller, Lon L. 1964. The Morality of Law. New Haven: Yale University Press.

Glendon, Mary Ann. 1993. Rights Talk: The Impoverishment of Political Discourse. NY: Free Press.

Holthouse, David. 2009. "The Year in Hate, 2008." Southern Poverty Law Center Intelligence Report 133, special issue (http://www.splcenter.org/get-informed/ intelligence-report/browse-all-issues/2009/spring/theyear-in-hate), accessed February 11, 2010.

Isaac, Jeffrey C., Robert Rohrschneider, Will Kymlicka, and Johnathan Laurence. 2008. "The Challenges of Multiculturalism in Advanced Democracies." Perspectives on Politics 6(4): 801-10.

Jackson, Thomas. 2004. What is Racism? (http://www. davidduke.com/general/what-is-racism_32.html), accessed February 11, 2010.

Kirkpatrick, David A. 2005. "From Alito's Past, a Window on Conservatives at Princeton." New York Times (November 27): A1.

Lawrence, Charles III. 1993. "If He Hollers Let Him Go: Racist Speech on Campus." In Words That Wound: Critical Race Theory, Assaultive Speech, And The First Amendment, eds. Mari J. Matsuda, Charles Lawrence III, and Richard Delgado. New York: Westview Press.

MacKinnon, Catharine. 1993. Only Words. Cambridge: Harvard University Press.

Mill, John Stuart. 1975. "On Liberty.” In Three Essays, ed. Richard Wollheim. Oxford: Oxford University Press.

Nozick, Robert. 1997. Socratic Puzzles. Cambridge: Harvard University Press.

Okin, Susan Moller. 2004. "Justice and Gender: An Unfinished Debate." Fordham Law Review 72: 1537-67.
Pickering v. Board of Education, 391 U.S. 563 (1968).

Pildes, Richard H. and Elizabeth Anderson. 2000. "Expressive Theories of Law: A General Restatement." University of Pennsylvania Law Review 148: 1503-75.

Rawls, John. 1993. Political Liberalism. Cambridge: Harvard University Press.

- 1999 [1971]. A Theory of Justice, revised ed. Cambridge: Harvard University Press. . 2001. Justice as Fairness: A Restatement. Cambridge (Mass.): Harvard University Press, 2001.

Rosenberger v. University of Virginia, 515 U.S. 819 (1995).

Rosenblum, Nancy L. 2000. Membership and Morals: The Personal Uses of Pluralism in America. Princeton: Princeton University Press.

Rust v. Sullivan, 500 U.S. 173 (1991).

Sandel, Michael. 1996. Democracy's Discontent: America in Search of a Public Philosophy. Cambridge: Harvard University Press.

Sniderman, Paul. 2007. When Ways of Life Collide: Multiculturalism and its Discontents in the Netherlands. Princeton: Princeton University Press.

Stevenson, Richard W. and Neil A. Lewis. 2006. "Democrats Take Aggressive Tack; Alito is Unfazed." New York Times (January 12): A1.

Sullivan, Kathleen M. 1989. "Unconstitutional Conditions." Harvard Law Review 102:1413-1506.

U.S. Bureau of Economic Analysis. "National Income and Product Accounts Table 1.1.5: Gross Domestic Product." (http://www.bea.gov/national/nipaweb/ TableView.asp? SelectedTable $=5 \&$ FirstYear $=2006 \&$ Last Year $=2007 \&$ Freq $=$ Qtr), accessed February 3, 2008.

Virginia v. Black, 538 U.S. 343 (2003).

Wertheimer, Alan. 1987. Coercion. Princeton: Princeton University Press. 